\title{
Optimization of a biolistic transformation system for transfer of antifreeze gene $K N 2$ and the bar herbicide resistance gene in common wheat
}

\author{
L. Cai ${ }^{1}$, D.F. Sun $^{1}$ and G.L. Sun ${ }^{1,2}$ \\ ${ }^{1}$ College of Plant Science and Technology, Huazhong Agricultural University, \\ Wuhan, China \\ ${ }^{2}$ Department of Biology, Saint Mary's University, Halifax, Nova Scotia, Canada \\ Corresponding authors: D.F. Sun / G.L. Sun \\ E-mail: sundongfa1@mail.hzau.edu.cn / genlou.sun@smu.ca
}

Genet. Mol. Res. 13 (2): 3474-3485 (2014)

Received January 28, 2013

Accepted June 28, 2013

Published April 30, 2014

DOI http://dx.doi.org/10.4238/2014.April.30.8

\begin{abstract}
We studied the effects of different media for callus induction and differentiation, and pre-culture period of immature wheat embryo culture on biolistic transformation efficiency for including antifreeze gene KN2 and bar conferring resistance to the herbicide bialaphos. The percentage of plantlets generated from induction and differentiation media without $\mathrm{Cu}^{2+}$ was lower than those cultured on differentiation media with $\mathrm{Cu}^{2+}(71.15 \%)$ or induction media with $\mathrm{Cu}^{2+}(68.45 \%)$ and both induction and differentiation media with $\mathrm{Cu}^{2+}$ $(52.17 \%)$. The combinations of Nor medium for callus induction and $\mathrm{Cu}^{2+}$ medium for regeneration, and $\mathrm{Cu}^{2+}$ medium for induction and $\mathrm{R}$ medium for regeneration were superior for biolistic transformation. The calli induced on $\mathrm{Cu}^{2+}$ medium and pre-cultured for $4 \mathrm{~d}$ before biolistic transformation, and cultured on $\mathrm{R}$ medium after biolistic transformation produced the highest percentage $(65 \%)$ of transgenic plantlets with the KN2 gene. Overall, about $50 \%$ plantlets regenerated from calli pre-
\end{abstract}


cultured $4 \mathrm{~d}$ before bombardment carried the $K N 2$ gene; $44.7 \%$ of the plantlets carried the bar gene, which was higher than for any other treatment, followed by pre-culture $1 \mathrm{~d}$ with $31.43 \%$ transformation rate for the KN2 gene and 20\% transformation rate for the bar gene.

Key words: Common wheat; Cold-resistance; Biolistic transformation; Antarctic fish superoxide dismutase gene

\section{INTRODUCTION}

Wheat (Triticum aestivum L.) is one of the staple food crops grown worldwide. Genetic engineering is widely used for improving agronomic traits, for instance, resistance or tolerance to biotic and abiotic stresses in wheat. Genetic transformation enables the introduction of novel genes directly into locally adapted cultivars to create new varieties (Jones et al., 2005). The first key requirement for a successful transformation system is a highly regenerable target tissue. Immature embryos has been the most widely used target and a range of culture medium components have been evaluated to enhance regeneration (Barro et al., 1999; Schulze, 2007; Sikandar et al., 2007). Among the DNA delivery methods, biolistic and Agrobacterium-mediated methods have played important roles in wheat transformation (Tao et al., 2011). The Agrobacterium-mediated method is an efficient system for dicotyledons, but is much less efficient for monocotyledons such as wheat, rice and corn, since monocotyledons have natural resistance to Agrobacterium infection (Ziolkowski, 2007). Currently, the biolistic system is widely used for DNA delivery in wheat (He and Lazzeri, 1998; Pellegrineschi et al., 2002; Hardwood, 2012). However, efficient transformation systems are usually developed for a single responsive genotype and are not transferrable to alternative genotypes, and challenges remain for the transformation of particular wheat cultivars (Hardwood, 2012).

Low temperature (cold and frost) has a significant negative impact on wheat productivity, and has become one of the serious abiotic stresses in wheat production in China in recent years. Chilling or freezing temperatures can lead to dysfunction and increased production of activated oxygen species such as superoxide, hydrogen peroxide and hydroxyl radicals (McKersie et al., 1993; Kuk et al., 2003). These reactive oxygen species can cause peroxidation of membrane lipids (Mead, 1976) and DNA strand breaks (Brawn and Fridovich 1981). Plants' first reaction against oxyradical-mediated injuries is the action of superoxide dismutases (SODs), a group of metalloenzymes that protect cells from superoxide radicals by catalyzing the dismutation of superoxide radicals to oxygen and hydrogen peroxide (Bowler et al., 1992). SODs are considered the first and most important line of antioxidant enzyme defense systems by removing the superoxide anion (Zelko et al., 2002), and has been proposed to be of importance in stress tolerance such as antifreeze activity. McKersie et al. $(1993,1996,1999)$ demonstrated that transgenic alfalfa expressing high levels of SOD displayed significantly high tolerance to freezing stress. Similar results have been obtained in transgenic tobacco (Gupta et al., 1993) and tomato (Wang et al., 2005).

In the present study, Antarctic fish superoxide dismutase gene, $K N 2$, was selected for the genetic transformation of T. aestivum, with the objective of developing transgenic plants with increased tolerance to freezing stress. The effect of different media for callus induction, differentiation and pre-culture before biolistic transformation of wheat immature embryo cultures on transformation efficiency of the antifreeze gene KN2 and bar gene, which confers 
resistance to the herbicide bialaphos, were studied. This protocol developed here could be used for developing transgenic plants, integrated with other agronomically important genes.

\section{MATERIAL AND METHODS}

\section{Plant materials and culture conditions}

Wheat variety Longchun 23 (L23) was used in this study. The immature embryos from L23 were collected from seeds in approximately 15 days after anthesis. The seeds were immersed in $70 \%$ ethanol for $1 \mathrm{~min}$, rinsed with sterile water once, and then immersed in $0.1 \%$ $\mathrm{HgCl}_{2}$ for $10 \mathrm{~min}$, followed by 4 rinses in sterile water and drying on filter paper. The immature embryos were aseptically excised from caryopses, placed with the scutellum upwards on 4 induction media (Nor, $\mathrm{Cu}^{2+}, \mathrm{Ag}^{+}$and N) (Table 1), and inoculated for 1-12 days in the dark at $25^{\circ} \mathrm{C}$. The cultured tissues were grown on osmotic medium for $4-6 \mathrm{~h}$ before bombardment.

Table 1. Media used in this study.

\begin{tabular}{|c|c|}
\hline Media & Compositions \\
\hline Induction medium (Nor) & $\begin{array}{l}\text { MS (Murashige and Skoog medium) }+500 \mathrm{mg} / \mathrm{L} \text { Casein Hydrolysates }+100 \mathrm{mg} / \mathrm{L} \text { glutamine }+100 \\
\mathrm{mg} / \mathrm{L} \text { proline }+10 \mathrm{mg} / \mathrm{L} \text { Vitamin } \mathrm{B}_{1}+40 \mathrm{~g} / \mathrm{L} \text { maltose }+2 \mathrm{mg} / \mathrm{L} 2,4-\mathrm{D}+8 \mathrm{~g} / \mathrm{L} \text { agar, } \mathrm{pH} 5.8\end{array}$ \\
\hline Induction medium $\left(\mathrm{Cu}^{2+}\right)$ & Nor medium $+1.25 \mathrm{mg} / \mathrm{L} \mathrm{CuSO}_{4}$, pH 5.8 \\
\hline Induction medium $\left(\mathrm{N}^{+}\right)$ & Nor medium with $5006 \mathrm{mg} / \mathrm{L} \mathrm{NH}_{4} \mathrm{NO}_{3}-\mathrm{KNO}_{3}$ \\
\hline Induction medium $\left(\mathrm{Ag}^{+}\right)$ & Nor medium $+2.5 \mathrm{mg} / \mathrm{L} \mathrm{AgNO}_{3}, \mathrm{pH} 5.8$ \\
\hline Osmotic medium & Nor medium $+0.2 \mathrm{M}$ mannitol $+0.2 \mathrm{M}$ sorbitol \\
\hline Differentiation medium (R) & $\begin{array}{l}\mathrm{MS}+500 \mathrm{mgL} \text { Casein Hydrolysates }+100 \mathrm{mg} / \mathrm{L} \text { glutamine }+100 \mathrm{mg} / \mathrm{L} \text { proline }+10 \mathrm{mg} / \mathrm{L} \mathrm{Vitamin} \\
\mathrm{B}_{1}+40 \mathrm{~g} / \mathrm{L} \text { maltose }+5 \mathrm{mg} / \mathrm{L} \text { kinetin }+8 \mathrm{~g} / \mathrm{L} \text { agar }+3 \mathrm{mg} / \mathrm{L} \text { bialaphos, } \mathrm{pH} 5.8\end{array}$ \\
\hline Differentiation medium $\left(\mathrm{Cu}^{2+}\right)$ & $\mathrm{R}$ medium $+0.25 \mathrm{mg} / \mathrm{L} \mathrm{CuSO}_{4}, \mathrm{pH} 5.8$ \\
\hline Regeneration medium & $\begin{array}{l}1 / 2 \mathrm{MS} \text { basic medium }+500 \mathrm{mg} / \mathrm{L} \text { Casein Hydrolysates }+100 \mathrm{mg} / \mathrm{L} \text { glutamine }+100 \mathrm{mg} / \mathrm{L} \text { proline }+ \\
10 \mathrm{mg} / \mathrm{L} \text { Vitamin } \mathrm{B}_{1}+30 \mathrm{~g} / \mathrm{L} \text { maltose }+8 \mathrm{~g} / \mathrm{L} \text { agar, } \mathrm{pH} 5.8\end{array}$ \\
\hline Root strengthening medium & $\begin{array}{l}\text { 1/2MS basic medium }+30 \mathrm{~g} / \mathrm{L} \text { maltose }+0.2 \mathrm{mg} / \mathrm{L} \text { naphthalene-acetic acid }+0.5 \mathrm{mg} / \mathrm{L} \text { paclobrtrazol }+ \\
8 \mathrm{~g} / \mathrm{L} \text { agar, } \mathrm{pH} 5.8\end{array}$ \\
\hline
\end{tabular}

\section{Plasmid vector, plasmid transformation and plasmid DNA isolation}

Plasmids pUBI::bar and pUBI::KN2, which contain the bar and KN2 gene, respectively, were kindly provided by the Genetics and Development Institute, Chinese Academy of Science. Both genes are under the control of the ubiquitin promoter and nos 3' terminator. Ampicillin was used as selectable marker (Figure 1).

For biolistic transformation, the plasmids were amplified in Escherichia coli DH5 $\alpha$ strain, transformed by routine heat-shock procedure. Plasmid DNA was isolated using the Tian Pure Mini Plasmid DNA isolation kit (Tiangen Biochemical Co., Beijing, China).

\section{Preparation and coating of gold particles with plasmid DNA}

One milliliter $96 \%$ ethanol was added to $20 \mathrm{mg}$ gold microcarrier particles, and the mixture was shaken for $2 \mathrm{~min}$ and centrifuged for $1 \mathrm{~min}$ at 13,000 rpm. The supernatant was removed and $1 \mathrm{ml}$ 96\% ethanol with gold microcarrier particles was added, and the above step repeated 3 times. Washing using $1 \mathrm{ml}$ sterile water was repeated 3 times, and after the final wash, particles were suspended in $1 \mathrm{ml}$ sterile water and kept at $-20^{\circ} \mathrm{C}$ until use. 

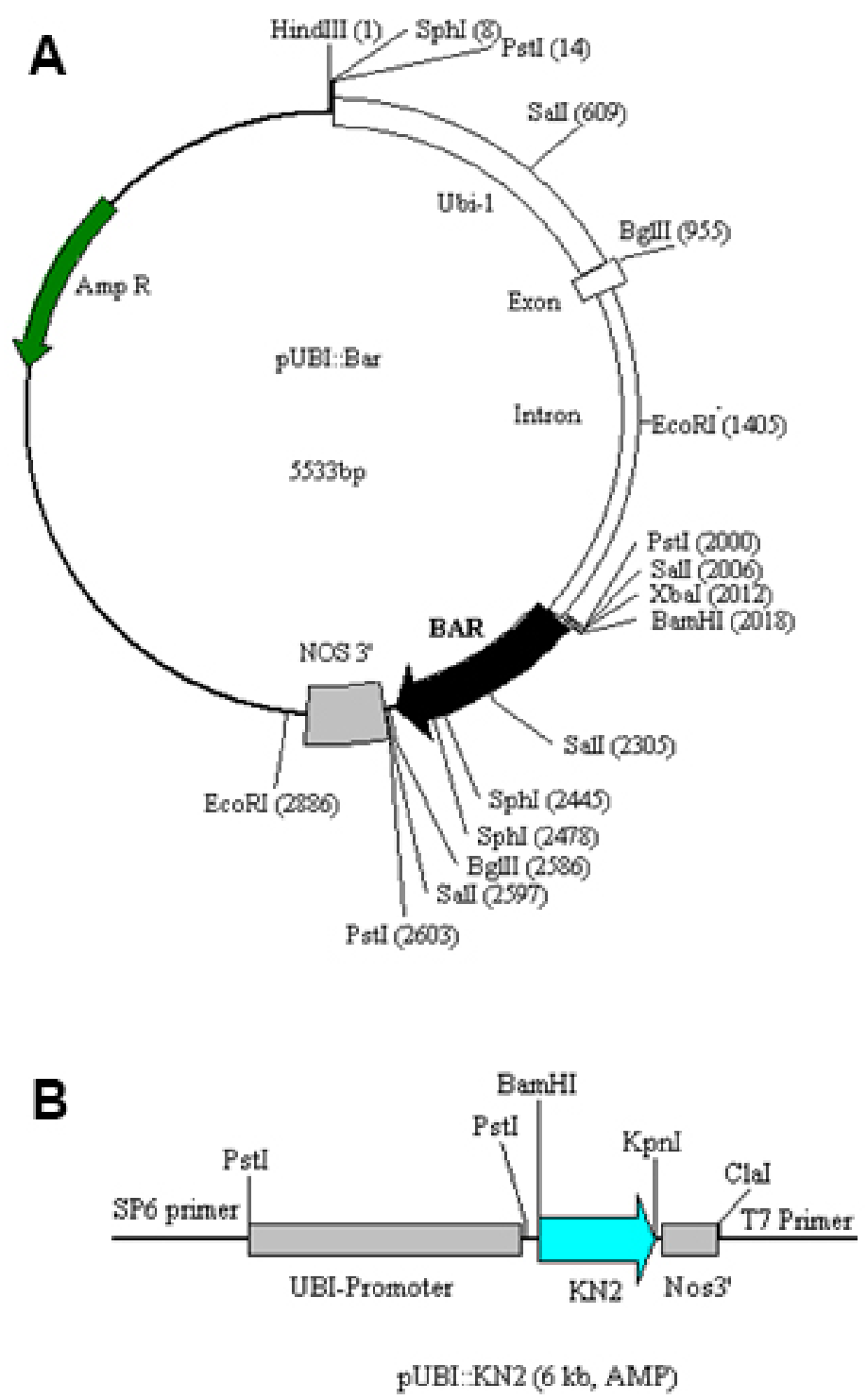

Figure 1. Vector maps of pUBI::bar (A) and pUBI::KN2 (B).

Each $5 \mu \mathrm{g}$ pBUI::bar and pUBI::KN2 plasmid DNA were separately added to each tube containing $35 \mu \mathrm{L}$ prepared gold microcarrier particles and mixed. Next, $50 \mu \mathrm{L} 2.5 \mathrm{M}$ $\mathrm{CaCl}_{2}$ and $20 \mu \mathrm{L} 0.1 \mathrm{M}$ spermidine were added, vortexed, and kept at room temperature for $10 \mathrm{~min}$. Particles were then pelleted by centrifugation for $1 \mathrm{~min}$ and the supernatant 
was discarded. Particles were washed once with $140 \mu \mathrm{L} 70 \%$ ethanol and once with $48 \mu \mathrm{L}$ absolute ethanol.

\section{Particle bombardment, differentiation, and regeneration of transformants}

Immature embryo-derived calli were bombarded 5-6 times at 1100 psi helium pressure, at a target distance of $6 \mathrm{~cm}$ and under a vacuum of $28 \mathrm{mmHg}$ with appropriate plasmid DNA coated microprojectiles by employing the Biolistic PDS-1000/He particle delivering system (Bio-Rad, USA). Bombardments with bar and KN2 were conducted on the same calli. Following bombardment, the calli were cultured on osmotic medium for 18 $\mathrm{h}$, transferred to induction medium for 15 days (see Table 1), and then transferred to two differentiation media $\left(\mathrm{R}, \mathrm{Cu}^{2+}\right)$ for 2 months at $25^{\circ} \mathrm{C}$, with a $16 / 8 \mathrm{~h}$ light/dark cycle. The healthy explants were subcultured on the differentiation media every 15 days. The regenerated plantlets were grown on regeneration medium for 30 days and then transferred to root strengthening medium. The rooted plantlets were vernalized at $4^{\circ} \mathrm{C}$ for 1 week and then transferred to pots to be grown until maturity at $25^{\circ} \mathrm{C}$.

\section{Genomic DNA isolation and PCR analysis}

Total genomic DNA was isolated from wheat leaves at the three-leaf stage using the CTAB method (Stein et al., 2001). PCR analysis of genomic DNA was carried out using 12-20 ng wheat DNA, $1.5 \mu \mathrm{M} \mathrm{MgCl}_{2}, 0.2 \mu \mathrm{M}$ of each primer, $0.2 \mu \mathrm{M}$ dNTPs, $0.04 \mathrm{U} T a q$ polymerase in a $25-\mu \mathrm{L}$ reaction volume. The forward and reverse primers used for amplification of the bar gene were 5'-CGGTCTGCACCATCGTAACCACT-3' and 5'-GAAACCCACGTCATGCCAGTTCCC-3' (Zhou et al., 2008). The primers used for amplification of the KN2 gene were 5'-TGCATCAGTGCAGGCCCTCAC-3' and 5'-CCTTTTCCCAGGTCGTCGGCC-3', which were designed by us using the Primer 3 software. The PCR protocols were as follows: for the bar gene, an initial denaturation at $95^{\circ} \mathrm{C}$ for $3 \mathrm{~min}, 35-40$ cycles of $94^{\circ} \mathrm{C}$ for $30 \mathrm{~s}, 62^{\circ} \mathrm{C}$ for $45 \mathrm{~s}, 72^{\circ} \mathrm{C}$ for $1 \mathrm{~min}$, and final extension at $72^{\circ} \mathrm{C}$ for $5 \mathrm{~min}$; for the $K N 2$ gene, an initial denaturation at $94^{\circ} \mathrm{C}$ for $5 \mathrm{~min}$, 35 cycles of $94^{\circ} \mathrm{C}$ for $30 \mathrm{~s}, 66^{\circ} \mathrm{C}$ for $45 \mathrm{~s}, 72^{\circ} \mathrm{C}$ for $1 \mathrm{~min}$, and final extension at $72^{\circ} \mathrm{C}$ for 5 min. The PCR products were run on a $1.5 \%$ agarose gel in $1 \mathrm{X}$ TAE along with a size marker.

\section{RESULTS}

\section{Effect of different induction media}

The effect of induction medium supplemented with $\mathrm{Cu}^{2+}, \mathrm{Ag}^{+}$or $\mathrm{N}^{+}$on callus induction from L23 was determined. The frequencies of induced calli on different media ranged from 95.28 to $97.33 \%$ (Table 2). Different induction media showed no effect on the frequency of induced callus, but showed an effect on the differentiation frequencies of calli in sequential culture on differentiation media. The differentiation frequency of calli was increased from $38.36 \%$ on the normal medium (Nor) to $42.99 \%$ on the medium with $\mathrm{Cu}^{2+}$. The media supplement with either $\mathrm{N}^{+}$or $\mathrm{Ag}^{+}$decreased the differentiation frequency of calli. In addition, the number of induced buds from the calli cultured on the medium with $\mathrm{Cu}^{2+}$ was higher than that 
on the other three media. The calli induced on the $\mathrm{Cu}^{2+}$ medium showed quick regeneration of plantlet when cultured on regeneration medium, and the regeneration rate $(64.95 \%)$ was higher for the calli induced on $\mathrm{Cu}^{2+}$ medium compared to the other media.

Table 2. Effect of callus induction media on L23 immature embryos culture and differentiation*.
\begin{tabular}{lcccccrc}
\hline Media & $\begin{array}{c}\text { No. of immature } \\
\text { embryos cultured }\end{array}$ & $\begin{array}{c}\text { No. of calli } \\
\text { induced }\end{array}$ & $\begin{array}{c}\text { \% of induced } \\
\text { calli }\end{array}$ & $\begin{array}{c}\text { No. of calli } \\
\text { differentiated }\end{array}$ & $\begin{array}{c}\text { \% of calli } \\
\text { differentiated** }\end{array}$ & $\begin{array}{c}\text { Plantlets } \\
\text { obtained }\end{array}$ & $\begin{array}{c}\% \text { of Plantlets } \\
\text { obtained }\end{array}$ \\
\hline $\mathrm{Nor}_{\mathrm{Cu}^{2+}}$ & 150 & 146 & $97.33 \%$ & 56 & $38.36 \%$ & 70 & $47.95 \%$ \\
$\mathrm{~N}^{+}$ & 220 & 214 & $97.28 \%$ & 92 & $42.99 \%$ & 139 & $64.95 \%$ \\
$\mathrm{Ag}^{+}$ & 178 & 170 & $95.28 \%$ & 50 & $29.41 \%$ & 43 & $25.29 \%$ \\
\hline
\end{tabular}

*The percentage (\%) of induced calli was calculated before biolistically transformation, the $\%$ of calli differentiated rate was calculated after biolistically transformation. **The callus differentiation data is a mean from two differentiation media $\left(\mathrm{Cu}^{2+}\right.$ and $\left.\mathrm{R}\right)$.

\section{$\mathrm{CuSO}_{4}$ effects}

The calli induced with induction media were transferred to the differentiation media $\mathrm{R}$ and $\mathrm{Cu}^{2+}$. More shoots were produced from the calli cultured on differentiation media with $\mathrm{CuSO}_{4}\left(\mathrm{Cu}^{2+}\right.$ medium) than on differentiation media without $\mathrm{CuSO}_{4}$ ( $\mathrm{R}$ medium) (Figure 2). A high percentage of calli induced on Nor medium subcultured on the differentiation medium supplemented with $\mathrm{Cu}^{2+}$ generated plantlets $(71.15 \%)$. The calli induced on the medium with $\mathrm{Cu}^{2+}$, subcultured on the differentiation medium without $\mathrm{Cu}^{2+}$ showed a $68.45 \%$ regeneration rate, and those subcultured on the differentiation medium $\mathrm{Cu}^{2+}$ showed a $52.17 \%$ regeneration rate. In general, the percentage of plantlets regenerated using both the induction and differentiation media without $\mathrm{Cu}^{2+}$ was much lower compared to culture on either differentiation medium with $\mathrm{Cu}^{2+}(71.15 \%)$ or induction medium with $\mathrm{Cu}^{2+}(68.45 \%)$ and both induction and differentiation media with $\mathrm{Cu}^{2+}(52.17 \%)$ (Table 3).

\section{Effect of culture period before transformation on L23 differentiation and genetic transformation}

Prior to bombardment, the immature embryos were cultured on induction media for $12,10,7,4$ and 1 days to test transformation efficiency. After transformation, the tissues were cultured for 15 days and then transferred to the differentiation medium $\mathrm{R}$ and $\mathrm{Cu}^{2+}$. The effects of pre-culture period and induction and differentiation media on biolistic transformation are presented in Table 4. The results showed that the calli induced on $\mathrm{Cu}^{2+}$ medium and pre-cultured for 4 days before biolistic transformation, and cultured on $\mathrm{R}$ medium after biolistic transformation produced the highest percentage $(65 \%)$ of transgenic plantlets with the KN2 gene (Table 4). PCR amplification of genomic DNA from explants using primers specific for the bar and $K N 2$ genes were used to identify the presence of transgenes in the transformants (Figure 3). The overall results showed that $50 \%$ of plantlets regenerated from calli pre-cultured 4 days before bombardment carried the KN2 gene and $44.7 \%$ of plantlets carried the bar gene, which was higher than with any other pre-culture treatments, followed by pre-cultured 1 day with a $31.43 \%$ transformation rate for $K N 2$ gene and $20 \%$ for bar gene (Table 5). 

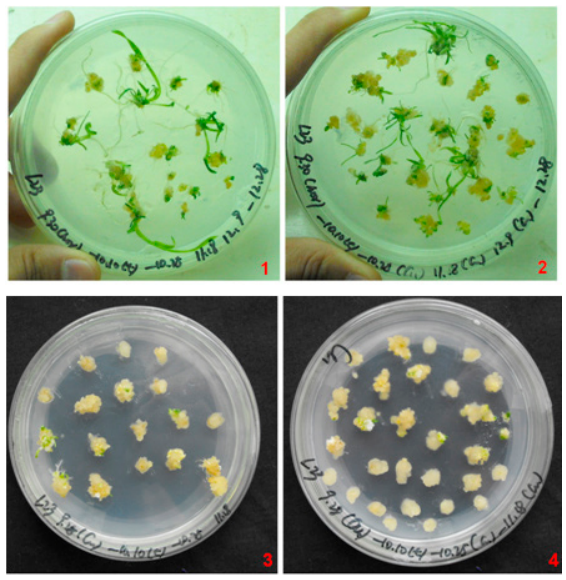

Figure 2. Callus induced on Nor induction media from immature embryos of L23 was transferred to differentiation media $\mathrm{R}$ (Figure 2.1) and $\mathrm{Cu}^{2+}$ (Figure 2.2). Figure 2.3 and 4 showed that callus induced on $\mathrm{Cu}^{2+}$ induction media from immature embryos of L23 was transferred to differentiation media R (Figure 2.3) and $\mathrm{Cu}^{2+}$ (Figure 2.4).

Table 3. Effects of $\mathrm{CuSO}_{4}$ on differentiation of $\mathrm{L} 23$ callus induced from four induction media*.

\begin{tabular}{|c|c|c|c|c|c|c|}
\hline \multirow[t]{2}{*}{$\begin{array}{l}\text { Differentiation } \\
\text { media }\end{array}$} & $\begin{array}{l}\text { No. of calli biolistically } \\
\text { transformed }\end{array}$ & $\begin{array}{l}\text { No. of calli } \\
\text { regenerated }\end{array}$ & $\%$ of regeneration & $\begin{array}{l}\text { No. of calli biolistically } \\
\text { transformed }\end{array}$ & $\begin{array}{l}\text { No. of calli } \\
\text { regenerated }\end{array}$ & $\%$ of regeneration \\
\hline & \multicolumn{3}{|c|}{ Nor } & \multicolumn{3}{|c|}{$\mathrm{Cu}^{2+}$} \\
\hline $\mathrm{Cu}^{2+}$ & 52 & 37 & $71.15 \%$ & 46 & 24 & $52.17 \%$ \\
\hline \multirow[t]{2}{*}{$\mathrm{R}$} & 94 & 33 & $35.11 \%$ & 168 & 115 & $68.45 \%$ \\
\hline & & $\mathrm{N}+$ & & \multicolumn{3}{|c|}{$\mathrm{Ag}^{+}$} \\
\hline$\overline{\mathrm{Cu}^{2+}}$ & 68 & 16 & $23.53 \%$ & 36 & 0 & 0 \\
\hline $\mathrm{R}$ & 102 & 27 & $26.47 \%$ & 86 & 13 & $15.12 \%$ \\
\hline
\end{tabular}

*The calli induced on four induction media, after biolistically transformation, the the biolistically transformed calli were cultured on differentiation media $\mathrm{Cu}^{2+}$ and $\mathrm{R}$.
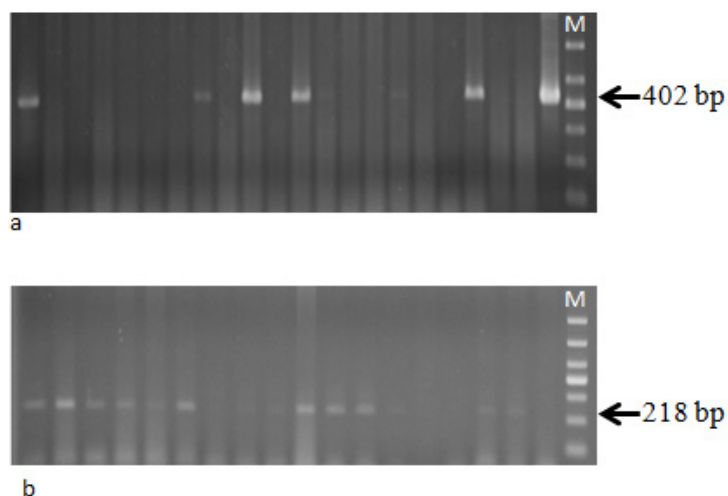

Figure 3. Examples of PCR analysis of transgenic plantlets. Lane $M=$ molecular marker, $100 \mathrm{bp}$; a. PCR analysis of the bar gene, expected size of the amplified bar gene is $402 \mathrm{bp}$; b. PCR analysis of the KN2 gene, expected size of the amplified KN2 gene is $218 \mathrm{bp}$. 
Table 4. Effects of pre-culture period, induction media, differentiation media on biolistic transformation of L23 immature embryos.

\begin{tabular}{|c|c|c|c|c|c|c|c|c|c|c|}
\hline \multicolumn{3}{|c|}{ Induction media } & \multicolumn{2}{|c|}{ Nor } & \multicolumn{2}{|c|}{$\mathrm{Cu}^{2+}$} & \multicolumn{2}{|c|}{$\mathrm{N}^{+}$} & \multicolumn{2}{|c|}{$\mathrm{Ag}^{+}$} \\
\hline \multicolumn{3}{|c|}{ Differentiation media } & $\mathrm{R}$ & $+\mathrm{Cu}^{2+}$ & $\mathrm{R}$ & $+\mathrm{Cu}^{2+}$ & $\mathrm{R}$ & $+\mathrm{Cu}^{2+}$ & $\mathrm{R}$ & $+\mathrm{Cu}^{2+}$ \\
\hline \multirow[t]{8}{*}{12 days } & \multicolumn{2}{|c|}{ No. of calli transformed } & 29 & - & 28 & 28 & 32 & - & - & - \\
\hline & \multirow[t]{2}{*}{ bar gene } & No. of positive plantlets & 4 & - & 12 & 0 & 4 & - & - & - \\
\hline & & Rate & $13.79 \%$ & - & $42.86 \%$ & 0 & $12.50 \%$ & - & - & - \\
\hline & \multirow[t]{2}{*}{$K N 2$ gene } & No. of positive plantlets & 1 & - & 14 & 0 & 3 & - & - & - \\
\hline & & Rate & $3.45 \%$ & - & $50.00 \%$ & 0 & $9.38 \%$ & - & - & - \\
\hline & \multicolumn{10}{|l|}{$b a r+K N 2$ gene } \\
\hline & \multirow[t]{2}{*}{ No. of positive plantlets } & 1 & - & 8 & 0 & 2 & - & - & - & \\
\hline & & Rate & $3.45 \%$ & - & $28.57 \%$ & 0 & $6.25 \%$ & - & - & - \\
\hline \multirow[t]{8}{*}{10 days } & \multicolumn{2}{|c|}{ No. of calli transformed } & 25 & 29 & 32 & - & 27 & - & 26 & - \\
\hline & \multirow[t]{2}{*}{ bar gene } & No. of positive plantlets & 6 & 5 & 13 & - & 0 & - & 3 & - \\
\hline & & Rate & $24.00 \%$ & $17.24 \%$ & $40.63 \%$ & - & 0 & - & $11.54 \%$ & - \\
\hline & \multicolumn{10}{|l|}{$K N 2$ gene } \\
\hline & \multicolumn{2}{|c|}{ No. of positive plantlets } & 3 & 9 & 6 & - & 0 & - & 4 & - \\
\hline & \multirow{3}{*}{ bar $+K N 2$ gene } & Rate & $12.00 \%$ & $31.03 \%$ & $46.15 \%$ & - & 0 & - & $15.38 \%$ & - \\
\hline & & No. of positive plantlets & 1 & 3 & 3 & - & 0 & - & 3 & - \\
\hline & & Rate & $4.00 \%$ & $10.34 \%$ & $23.08 \%$ & - & 0 & - & $11.54 \%$ & - \\
\hline \multirow[t]{7}{*}{7 days } & \multicolumn{2}{|c|}{ No. of calli transformed } & 40 & 23 & 54 & - & 45 & 68 & 25 & 36 \\
\hline & \multirow[t]{2}{*}{ bar gene } & No. of positive plantlets & 1 & 2 & 9 & - & 6 & 3 & 0 & 0 \\
\hline & & Rate & $2.50 \%$ & $8.70 \%$ & $16.67 \%$ & - & $13.33 \%$ & $4.41 \%$ & 0 & 0 \\
\hline & \multirow[t]{2}{*}{$K N 2$ gene } & No. of positive plantlets & 1 & 9 & 12 & - & 5 & 1 & 0 & 0 \\
\hline & & Rate & $2.50 \%$ & $39.13 \%$ & $22.22 \%$ & - & $11.11 \%$ & $1.47 \%$ & 0 & 0 \\
\hline & \multirow[t]{2}{*}{$b a r+K N 2$ gene } & No. of positive plantlets & 0 & 0 & 3 & - & 2 & 0 & 0 & 0 \\
\hline & & Rate & 0 & 0 & $5.56 \%$ & - & $4.44 \%$ & 0 & 0 & 0 \\
\hline \multirow[t]{7}{*}{4 days } & No. of cal & ansformed & - & - & 20 & 18 & - & - & 35 & - \\
\hline & bar gene & No. of positive plantlets & - & - & 6 & 9 & - & - & 2 & - \\
\hline & $K N 2$ gene & Rate & - & - & $30.00 \%$ & $50.00 \%$ & - & - & $5.71 \%$ & - \\
\hline & No. of pos & e plantlets & - & - & 13 & 6 & - & - & 0 & - \\
\hline & & Rate & - & - & $65.00 \%$ & $33.33 \%$ & - & - & 0 & - \\
\hline & bar $+K N 2$ gene & No. of positive plantlets & - & - & 6 & 1 & - & - & 0 & - \\
\hline & & Rate & - & - & $30.00 \%$ & $5.56 \%$ & - & - & 0 & - \\
\hline 1 day & No. of cal & insformed & - & - & 35 & - & - & - & - & - \\
\hline & bar gene & No. of positive plantlets & - & - & 7 & - & - & - & - & - \\
\hline & & Rate & - & - & $20.00 \%$ & - & - & - & - & - \\
\hline & $K N 2$ gene & No. of positive plantlets & - & - & 11 & - & - & - & - & - \\
\hline & & Rate & - & - & $31.43 \%$ & - & - & - & - & - \\
\hline & bar $+K N 2$ gene & No. of positive plantlets & - & - & 4 & - & - & - & - & - \\
\hline & & Rate & - & - & $11.43 \%$ & - & - & - & - & - \\
\hline
\end{tabular}

(-) data not available.

Table 5. Effects of culture period before transformation on L23 differentiation and genetic transformation.

\begin{tabular}{lccccc}
\hline $\begin{array}{l}\text { Pre-culture time } \\
\text { before bombardment }\end{array}$ & $\begin{array}{c}\text { No. of regenerated } \\
\text { plantlets }\end{array}$ & $\begin{array}{c}\text { No. of plantlet } \\
\text { with bar gene }\end{array}$ & $\begin{array}{c}\text { Transformation rate } \\
\text { of } \text { bar gene }\end{array}$ & $\begin{array}{c}\text { No. of plantlet } \\
\text { with } K N 2 \text { gene }\end{array}$ & $\begin{array}{c}\text { Transformation rate } \\
\text { of } K N 2 \text { gene }\end{array}$ \\
\hline 12 days & 50 & 20 & $17.54 \%$ & 18 & $15.79 \%$ \\
10 days & 56 & 27 & $19.42 \%$ & 22 & $15.83 \%$ \\
7 days & 96 & 21 & $7.22 \%$ & 28 & $9.72 \%$ \\
4 days & 38 & 17 & $44.74 \%$ & 19 & $50.00 \%$ \\
1 day & 18 & 7 & $20.00 \%$ & 11 & $31.43 \%$ \\
\hline
\end{tabular}

\section{DISCUSSION}

$\mathrm{Cu}^{2+}$ is a cofactor of many enzymes, such as polyphenol oxidase and ascorbic acid oxidase in metabolic pathways, and an essential element for plant growth and development. 
Previous studies have suggested that $\mathrm{Cu}$ enzymes could play an important role in plant tissue culture (Purnhauser, 1991; Purnhauser and Gyulai, 1993). Purnhauser (1991) examined the effects of six copper levels on regeneration from callus cultures in hexaploid wheat and found that regeneration rates were eight times higher on medium containing $10 \mu \mathrm{M} \mathrm{CuSO}_{4}$ than on the original MS copper level $(0.1 \mu \mathrm{M})$. Similar results were also found for wheat anther cultures and triticale immature embryo-derived callus (Purnhauser and Gyulai, 1993). Ghaemi et al. (1994) tested the effects of different copper levels on the production of embryoids from anthers of tetraploid wheat (T. turgidunt L.), and found that the addition of $40 \mu \mathrm{M} \mathrm{CuSO}_{4}$ to the medium significantly increased embryoid production in three of the four genotypes tested. Chen et al. (2004) showed a positive correlation between the rate of wheat callus regeneration and concentration of $\mathrm{Cu}^{2+}$ in the culture medium, and suggested that the optimal concentration of $\mathrm{Cu}^{2+}$ for wheat tissue culture is $5 \mu \mathrm{M}$. In rice, Yang et al. $(1999 \mathrm{a}, \mathrm{b})$ showed that an increased level of copper in the culture medium dramatically improves the proliferation and regeneration rate of calli. Yu et al. (2008) observed that a greater number of plantlets regenerated on medium containing $2 \mathrm{mg} / \mathrm{L}(\sim 8 \mu \mathrm{M}) \mathrm{CuSO}_{4}$ survived, which may have resulted from an increased number of well-developed roots. In general, our results here correspond well with previous studies, suggesting that the micronutrient copper in the induction medium (1.25 $\mathrm{mg} / \mathrm{L}, \sim 5 \mu \mathrm{M})$ can increase the differentiation rate and regeneration rate of wheat calli.

The effect of silver nitrate on somatic embryogenesis and plant regeneration in several plant species has been investigated, for example, Brassica ssp (Kuvshinov et al., 1999), rice (Adkins et al., 1993), and barley (Castillo et al., 1998). In wheat, the effects of silver nitrate on somatic embryogenesis and plant regeneration have also been studied. Purnhauser et al. (1987) first reported that $10 \mathrm{mg} / \mathrm{L} \mathrm{AgNO}_{3}$ effectively promoted wheat shoot regeneration from calli derived from immature embryos. Chen et al. (2006) suggested that the induction medium supplemented with $0.1 \mathrm{mg} / \mathrm{L} \mathrm{ABA} \mathrm{(abscisic} \mathrm{acid)} \mathrm{and} 2.5$ or $5.0 \mathrm{mg} / \mathrm{L} \mathrm{AgNO}_{3}$ enhanced induction of calli and differentiation of wheat calli. Yu et al. (2008) optimized the culture system for mature embryo-based callus induction and plant regeneration for elite wheat cultivars grown in China, and found that the addition of $10 \mathrm{mg} / \mathrm{L} \mathrm{AgNO}_{3}$ in regeneration medium promoted plant regeneration. Fernandez et al. (1999) found that the addition of $1 \mathrm{mg} / \mathrm{L} \mathrm{AgNO}_{3}$ to the medium improved the induction of somatic embryogenesis in durum wheat. In our study, the lowest regeneration rate (15.12\%) was found for the calli induced from medium with $\mathrm{AgNO}_{3}$ used for biolistic transformation. Our results disagreed with previous findings, and suggested that $\mathrm{AgNO}_{3}$ decreased the plantlet regeneration and transformation rate. In previous studies, the healthy or undamaged calli were cultured on the medium supplemented with $\mathrm{AgNO}_{3}$. In this study, bombardment was used to introduce foreign genes into host cells. Microcarriers used for biolistic transformation usually damage cells by perforating them and allowing cytoplasm to escape (Greer et al., 2009). The calli induced on $\mathrm{AgNO}_{3}$ medium may contain $\mathrm{Ag}^{+}$, which may inhibit cell differentiation and growth. It is also possible that $\mathrm{AgNO}_{3}$ interacts with gold microcarrier particles to inhibit the induction and differentiation of calli.

Nitrogen is one of the major macronutrients required for plant growth and development. Mordhorst and Lörz (1993) claimed that nitrogen content strongly affected the development of barley microspores, and that optimal nitrogen content was between 20 and $35 \mathrm{mM}$. Nitrogen effects are highly dependent on both total amount of nitrogen and proportion of $\mathrm{NH}_{4}^{+}$and $\mathrm{NO}_{3}^{-}$, and affect a wide range of in vitro responses, including callus growth, shoot and root organogenesis, embryogenesis, and shoot multiplication (George and Klerk, 2008). A 
strong positive correlation was found between the increase in the number of regenerated embryos and the increase in the number of regenerated plants in Superb cultivar exposed to high concentrations of nitrogen (Greer et al., 2009). It was found that increasing nitrogen content 3- and 6-fold resulted in respective 8.4- and 13.4-fold increases in the regeneration of plantlets from the bombarded scutella (Greer et al., 2009). However, in our study, the high concentration of nitrogen in induction medium did not show an increase in regeneration of plantlets. No strong connection between content of nitrogen and somatic embryogenesis yield in wheat was reported by Menke-Milczarek and Zimny (2001). Grimes and Hodges (1990) found the level of nitrogen did not significantly affect the number of regenerated rice plants. It was suggested that each species, cultivar and even tissue has its own unique preference for different salt concentration (He et al., 1989; Maës et al., 1996). Greer et al. (2009) also found that the nitrogen content used was ideal for regenerating the cultivar Superb, but was suboptimal for regenerating other cultivars. Thus, the effect of nitrogen on the induction and regeneration of calli is cultivar dependent.

The condition of the host is an important factor determining the success rate of genetic transformation. Using explants at an optimal developmental stage for genetic transformation can improve the transformation efficiency. The duration of immature embryo culture before bombardment is one of the important factors. It has been reported that transformation can be dependent on the pre-culture period (Gless et al., 1998). A study on the transformation of immature maize embryos found that transformation frequency was greatly increased when the scutella were pre-cultured for 2-6 days (Brettschneider et al., 1997). With triticale scutellum tissue, a clear reduction in tissue damage was achieved when the explants were pre-cultured for 2-7 days (Zimny et al., 1995). Takumi and Shimada (1996) showed that embryos cultured for less than 4 day before bombardment failed to produce transformed plants, and transgenic wheat plants were obtained from the immature embryos pre-cultured 5 days or more prior to bombardment. However, a culture of leaf segments of longer than 2 days prior to bombardment led to a 33\% decrease in transient expression events in oats (Gless et al., 1998). Our results showed that wheat immature embryos pre-cultured for 4 days are more suitable for genetic transformation than the embryos pre-cultured more than 4 days.

\section{ACKNOWLEDGMENTS}

Research supported by the Chinese Transgenic Program (\#2011ZX08002004) and the “863” Project (\#2011AA10A106).

\section{REFERENCES}

Adkins SW, Kunanuvatchaidach R, Gray SJ and Adkins AL (1993). Effect of ethylene and culture environment on rice callus proliferation. J. Exp. Bot. 44: 1829-1835.

Barro F, Martin A, Lazzeri PA and Barceló P (1999). Medium optimization for efficient somatic embryogenesis and plant regeneration from immature inflorescences and immature scutella of elite cultivars of wheat, barley and tritordeum. Euphytica 108: 161-167.

Bowler C, Montagu MV and Inze D (1992). Superoxide dismutase and stress tolerance. Ann. Rev. Plant Physiol. Plant Mol. Biol. 43: 83-116.

Brawn K and Fridovich I (1981). DNA strand scission by enzymically generated oxygen radicals. Arch. Biochem. Biophys. 206: 414-419.

Brettschneider R, Becker D and Lörz H (1997). Efficient transformation of scutellar tissue of immature maize embryos. Theor. Appl. Genet. 94: 737-748. 
Castillo AM, Egaña B, Sanz JM and Cistué L (1998). Somatic embryogenesis and plant regeneration from barley cultivars grown in Spain. Plant Cell Rep. 17: 902-906.

Chen YF, Wang LM, Ding YJ and Li CL (2004). Effect of copper on differentiation and high frequency regeneration of immature embryos in wheat (Triticum aestivum L.). J. Northwest Sci.-Tech. Univ. Agric. Forest. 32: 1-4.

Chen JY, Wen FX, He SL and Chen XJ (2006). Effect of ABA and AgNO3 on calli induction and differentiation of immature wheat embryo. J. Triticeae Crops 26: 46-48.

Fernandez S, Michaux-Ferriere N and Coumans M (1999). The embryogenic response of immature embryo cultures of durum wheat (Triticum durum Desf): histology and improvement by AgNO3. Plant Growth Regul. 28: 147-155.

George EF and Klerk GJ (2008). The Components of Plant Tissue Culture Media I: Macro- and Micro-Nutrients. In: Plant Propagation by Tissue Culture (George EF, Hall MA and Klerk G-J, eds.). 3rd edn. Springer, Dordrecht, 65-113.

Ghaemi M, Sarrafi A and Alibert G (1994). The effects of silver nitrate, colchicines, cupric sulfate and genotype on the production of embryoids from anthers of tetraploid wheat (Triticum turgidium). Plant Cell Tissue Organ Cult. 36: 355-359.

Gless C, Lörz H and Jähne-Gärtner A (1998). Transgenic oat plants obtained at high efficiency by microprojectile bombardment of leaf base segments. J. Plant Physiol. 152: 151-157.

Greer MS, Kovalchuk I and Eudes F (2009). Ammonium nitrate improves direct somatic embryogenesis and biolistic transformation of Triticum aestivum. N. Biotechnol. 26: 44-52.

Grimes HD and Hodges TK (1990). The inorganic NO3-: NH4+ ratio influences plant regeneration and auxin sensivity in primary callus derived from immature embryo of Indica rice (Oryza sativa L.). J. Plant Physiol. 136: 362-367.

Gupta AS, Webb RP, Holaday AS and Allen RD (1993). Overexpression of superoxide dismutase protects plants from oxidative stress (Induction of Ascorbate Peroxidase in Superoxide Dismutase-Overexpressing Plants). Plant Physiol. 103: 1067-1073.

Hardwood WA (2012). Advances and remaining challenges in the transformation of barley and wheat. J. Exp. Bot. 63: 1791-1798.

He DG, Yang YM and Scott KJ (1989). The effect of macroelements in the induction of embryogenic callus from immature embryos of wheat (Triticum aestivum L.). Plant Sci. 64: 251-258.

He GY and Lazzeri PA (1998). Analysis and optimization of DNA delivery into wheat scutellum and Tritodeum inflorescence explants by tissue electroporation. Plant Cell Rep. 18: 64-70.

Jones HD, Doherty A and Wu H (2005). Review of methodologies and a protocol for the Agrobacterium-mediated transformation of wheat. Plant Methods 1: 5.

Kuk YI, Shin JS, Burgos NR and Hwang TE (2003). Antioxidative enzymes offer protection from chilling damage in rice plants. Crop Sci. 43: 2109-2117.

Kuvshinov V, Koivu K, Kanerva A and Pehu E (1999). Agrobacterium tumefaciens-mediated transformation of greenhouse-grown Brassica rapa ssp. oleifera. Plant Cell Rep. 18: 773-777.

Maës OC, Chibbar RN, Caswell K and Leung N (1996). Somatic embryogenesis from isolated scutella of wheat: effects of physical, physiological and genetic factors. Plant Sci. 121: 75-84.

McKersie BD, Chen Y, de Beus M, Bowley SR, et al. (1993). Superoxide dismutase enhances tolerance of freezing stress in transgenic alfalfa (Medicago sativa L.). Plant Physiol. 103: 1155-1163.

McKersie BD, Bowley SR, Harjanto E and Leprince O (1996). Water-deficit tolerance and field performance of transgenic alfalfa overexpressing superoxide dismutase. Plant Physiol. 111: 1177-1181.

McKersie BD, Bowley SR and Jones KS (1999). Winter survival of transgenic alfalfa overexpressing superoxide dismutase. Plant Physiol. 119: 839-848.

Mead JF (1976). Free Radical Mechanisms of Lipid Damage and Consequences for Cellular Membranes. In: Free Radical in Biology (Pryor WA, ed.). Vol. 1. Academic Press, New York, 51-68.

Menke-Milczarek I and Zimny J (2001). NH4+ and NO3- requirement for wheat somatic embryogenesis. Acta Physiol. Plant 23: 37-42.

Mordhorst AP and Lörz H (1993). Embryogenesis and development of isolated barley (Hordeum vulgare L.) microspores are influenced by the amount and composition of nitrogen sources in culture media. Plant Physiol. 142: 485-492.

Pellegrineschi A, Noguera LM, Skovmand B, Brito RM, et al. (2002). Identification of highly transformable wheat genotypes for mass production of fertile transgenic plants. Genome 45: 421-430.

Purnhauser L, Medgyesy P, Czakó M and Dix PJ (1987). Stimulation of shoot regeneration in Triticum aestivum and Nicotiana plumbaginifolia Viv. Tissue cultures using the ethylene inhibitor AgNO3. Plant Cell Rep. 6: 1-4.

Purnhauser L (1991). Stimulation of shoot and root regeneration in wheat Triticum aestivum callus cultures by copper. Cereal Res. Comm. 19: 419-423.

Purnhauser L and Gyulai G (1993). Effect of copper on shoot and root regeneration in wheat, triticale, rape and tobacco tissue cultures. Plant Cell Tissue Organ Cult. 35: 131-139.

Genetics and Molecular Research 13 (2): 3474-3485 (2014)

CFUNPEC-RP www.funpecrp.com.br 
Schulze J (2007). Improvement in cereal tissue culture by thidiazuron: a review. Fruit Vegetable Cereal Sci. Biotechnol. 1: 64-79.

Sikandar, Ali W, Khan I and Munir I (2007). Optimization of in vitro condition for callus induction, proliferation and regeneration in wheat (Triticum aestivum L.) cultivars. Biotechnology 6: 420-425.

Stein N, Herren G and Keller B (2001). A new DNA extraction method for high-throughput marker analysis in a largegenome species such as Triticum aestivum. Plant Breed. 120: 354-356.

Takumi S and Shimada T (1996). Production of transgenic wheat through particle bombardment of scutellar tissues: frequency is influenced by culture duration. J. Plant Physiol. 149: 418-423.

Tao LL, Yin GX, Du LP and Shi ZY (2011). Improvement of plant regeneration from immature embryos of wheat infected by Agrobacterium tumefaciens. Agr. Sci. China 10: 317-326.

Wang Y, Wisniewski M, Meilan R and Cui M (2005). Overexpression of cytosolic ascorbate peroxidase in tomato confers tolerance to chilling and salt stress. J. Am. Soc. Hortic. Sci. 130: 167-173.

Yang YS, Zheng GC and Jian YY (1999a). A further study on the effects of copper in rice callus culture. Chin. J. Rice Sci. 13: 245-247.

Yang YS, Jian YY and Zheng YD (1999b). Copper enhances plant regeneration in callus culture of rice. Chin. J. Rice Sci. 13: 95-98.

Yu Y, Wabg J, Zhu ML and Wei ZM (2008). Optimization of mature embryo-based high frequency callus induction and plant regeneration from elite wheat cultivars grown in China. Plant Breed. 127: 249-255.

Zelko IN, Mariani TJ and Folz RJ (2002). Superoxide dismutase multigene family: a comparison of the CuZn-SOD (SOD1), Mn-SOD (SOD2), and EC-SOD (SOD3) gene structures, evolution, and expression. Free Radic. Biol. Med. 33: 337-349.

Zhou MP, Yu GH, Ren LJ and Zhu WF (2008). Screening of transgenic wheat plants resistant to herbicide. J. Triticeae Crops 28: 935-940.

Zimny J, Becker D, Brettschneider R and Lörz H (1995). Fertile, transgenic Triticale (x Triticosecale Wittmack). Mol. Breed. 1: 155-164.

Ziolkowski MJ (2007). Advancements in biolistics and applications for agriculturally significant crops. Microbiol. Mol. Genet. 3: 34-39. 